\title{
A HISTORICAL PERSPECTIVE AND PROSPECTS OF BIOMEDICAL RESEARCH ON PARASITIC DISEASES
}

\author{
Augusto SIMÕES-BARBOSA(1), Constança SIMÕES BARBOSA(2) \& Frederico SIMÕES BARBOSA(2)
}

\begin{abstract}
SUMMARY
We all hope that biotechnology will answer some social and economical unavoidable requirements of the modern life. It is necessary to improve agriculture production, food abundance and health quality in a sustainable development. It is indeed a hard task to keep the progress on taking into account the rational use of genetic resources and the conservation of biodiversity. In this context, a historical perspective and prospects of the biomedical research on parasitic diseases is described in a view of three generations of investigators. This work begins with a picture of the scientific progress on biomedical research and human health over the last centuries. This black-and-white picture is painted by dissecting current advancements of molecular biology and modern genetics, which are outlined at the meaning of prospecting achievements in health science for this new millenium.
\end{abstract}

KEYWORDS: Public health; Biotechnology; Genome sequencing; Parasitic diseases.

Public health achievements and biomedical research on the last centuries: Progresses of medicine and public health were lever up at the middle of $19^{\text {th }}$ century as a consequence of the industrial revolution. Arm workers were the functional parts of the capitalism machinery. The wear and tear of these parts was a concern for the industrial productivity. Moreover, epidemic diseases were spreading over the overgrowing cities, reaching the dominant classes ${ }^{28}$.

There was no way to recognize the diseases and their etiologies. Scientists believed air and water pollution was related to ailments ${ }^{32}$. Overcrowding cities and sanitary deprivation were adjuvants for dissemination of infectious diseases. Due to this situation, investments on public health became obviously necessary.

Strict state's sanitary inspection orders were evacuate and demolish the slum tenements, as a way of "cleaning the cities". Urban peripheries raised together with the misunderstanding and dissatisfaction of the citizens. Oswaldo Cruz, for instance, was a target of social reaction while controlling yellow fever. Actually, he became a victim of governmental imposition. Naturally, benefits of his work were recognized and today Oswaldo Cruz is considered one of the greatest sanitarian of that century ${ }^{31}$.

The end of the $19^{\text {th }}$ century was marked by statistical measurements. Health was measured in terms of statistical indexes correlated with biological and socioeconomical parameters. At least, these data have revealed the social disparities in health. The epidemiology appeared as a science searching for factors, in a meta and multi analysis, which could determine the presence of diseases. Therefore, epidemiology and statistics have contributed to predict, control and interfere in diseases.

At this period, the microbial theory of diseases became evident due to advancements on microscopy and microbiology. In this context, Brazil was the main scenario for the birth of the tropical medicine supported by the interest of scientific European community and the presence of a competent technical staff for the development of health technology. The Oswaldo Cruz Institute was known as the pioneer research center where brilliant scientists, such as Oswaldo Cruz, Vital Brasil and Carlos Chagas contributed to tropical medicine.

New drugs, antibiotics, vaccines and technologies were developed at the middle of $20^{\text {th }}$ century. A work plan on disease control could be established for diseases such as malaria, syphilis, tuberculoses, leprosy, diphtheria, polio, measles, tetanus and whooping cough. The vaccination has covered $80 \%$ of the population as an attempt to eradicate some of these diseases ${ }^{7}$. This fact was accomplished by massive delivering of pure drinking water, sewage and garbage disposal. Moreover, scientific discoveries have alerted people about behaviors which were harmful for their health.

Since 1930-40, as a result of social pressure in an economical crisis postwar, Brazil has been experiencing the raising of institutional social securities and rights for all levels of employees, such as medical assistance, pensions, retirement and others. The result is the reduction of child mortality, infectious diseases, and the increment of the expectation of life. However, the index of mortality caused by infectious diseases is $33 / 100,000$ habitants ${ }^{39}$. This high rate is due to poverty and absence of health conditions

(1) Pós-graduação em Biotecnologia, Universidade Católica de Brasília, SGAN 916, 70790-160 Brasília, DF, Brasil.

(2) Fundação Oswaldo Cruz, Centro de Pesquisas Aggeu Magalhães, Campus da UFPE, 50670-420 Recife, PE, Brasil.

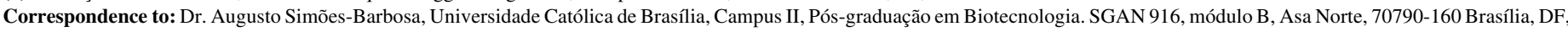
Brasil. Telephone: +55 61340 5550. Fax: +55 61340 5550. E-mail: sbarbosa@ucb.br 
for millions of people. The lack of uniform revenue distribution transforms our country in one of the most social disparities in the world. Poverty, uncontrolled human migrations, ecological disasters, absence of urban infrastructure and decrement of life quality make difficult to control and eradicate some diseases such as tuberculosis, intestinal parasitoses, dengue, malaria, Chagas disease, schistosomiasis. In this field, the science has reached its objective, it is time to political decisions.

Biological sciences can still contribute to elucidate the mechanisms of parasite survival and virulence. There was no vaccine for all pathogens. New pathogens and some examples of conventional drug resistance parasite strains imply continuos investigation. In fact, refinement of such technologies for investigation is necessary to go further on the comprehension of the biology of parasite and host-parasite interactions. The biotechnology appears as a promise for the comprehension of such mechanisms at the basis of elucidating genetic information and developing new tools for disease intervention.

Parasitic diseases and the biotechnology: Several species are competing for surviving in a rich planet where the resources are variable but limited. Species can share resources but they can rarely occupy the same ecological niche. This fact creates a disharmonic relationship and sometimes leads to competitive exclusion. Parasitism is an ecological relationship among different species, almost always disharmonic. However, evolution plays its role over the natural history whenever is possible: the coexistence of different species.

A parasite must present peculiar adaptation since the host organism is its environment. Blood, gastrointestinal or genitourinary tracts seem to be, at first sight, complex and aggressive environments. Once again, evolution takes place, modeling the parasites good experts on evading or even taking advantage of such condition.

Genome modification is the main result of evolution. Coevolution of host and parasite results in modification of both genomes in attempt for reproduction and surviving. Genetic variability is the molecular basis for understanding some intriguing facts, such as host resistance, parasite virulence, acquired drug resistance and immune evasion. For this reason, genome sequencing projects can provide real and valuable information.

Therefore, current development of immunogenetics, molecular biology and modern genetics has opened new possibilities for the human health. The biotechnology could be defined as the rational use of this knowledge and tools to give us the answers which are necessary for intervening in a biological process, such as a disease.

Accessing the genome information: There are several evidences that genetic factors play a role in determining susceptibility to many infectious diseases. Initially, alleles from the major histocompatibility complex were recognized to be implicated in this process ${ }^{35,36}$. The identification of such alleles can be limited to a specific human population. The geographical heterogeneity is related to some intrinsic variables, such as genetic variation of the parasite antigens. The reverse immunogenetics has permitted the characterization of the T cell epitope associated with this polymorphism ${ }^{4,9}$.

Nowadays, we know that several non-MHC genes can also play a role in pathogenicity of genetic and infectious diseases. Familial studies have indicated that "background" genes may be implicated in diseases ${ }^{37}$. The complete comprehension of a pathology may help to preview candidate gene polymorphism. For example, approximately twelve genes related to malaria susceptibility in certain human populations were described $^{15}$. Sometimes, a candidate gene approach is not feasible. In that case, the development of microsatelite markers has revolutionized the genetic linkage studies. Hundreds of microsatelites are dispersed in intervals of $10 \mathrm{cM}$ or 10 megabases. It is possible to follow the segregation of markers in a familial study. The sharing of a genetic marker among slibings affected by the disease indicates that the marker cosegregates with the susceptibility gene ${ }^{27}$. Further intensive work is necessary to reach the fine mapping of the gene.

There are some molecular techniques which allow the genetic discrimination of individuals belonging to the same specie. In one hand, this will lead us to think about our specie concepts, on the other hand, these techniques are successfully being taken in studies of molecular epidemiology ${ }^{24}$. Characterization of rDNA sequences and their nontranscribed spacers is being used to discriminate parasite isolates ${ }^{16,17}$. Random amplification of polymorphic DNA (RAPD) is achieved by a low-stringent PCR with short and arbitrary oligonucleotides as the primers of reaction. RAPD is usually performed with several arbitrary primers. Each RAPD reaction usually leads to multiloci analysis. Efforts are being spent for the development of parasite genome microsatelite markers ${ }^{34}$.

Moving from putative loci or candidate genes to the right gene(s) responsible for the disease can take time and several studies with different populations. Identification of expressed sequence tags (EST) and their chromosomal locations (transcript map) in human genome projects, for instance, will speed up this step ${ }^{1}$.

The current modern genetics is producing genetic maps, physical maps and complete nucleotide sequences ${ }^{18}$. Nowadays, DNA sequencing projects have provided the complete genomic sequences of 141 viruses, 51 organelles, two eubacteria, one archeon, and one eukaryote (Sacharomyces cerevisiae). Among genome projects, it has been announced the first, almost complete, sequencing of the human genome $\mathrm{e}^{30}$. There are some genome projects of human parasites in progress, mostly Plasmodium, trypanosomatids and Schistosoma ${ }^{2,40}$. The next step is to understand the functional genome which tries to explain how hundred thousands of genes control the organism's life in response to the environment resulting in genetic variability.

Because of our accumulative knowledge in this area together with the rapidly development of robotics and bioinformatics, the biological research is entering in a genomic era. The high-throughput sequencing will soon provide a whole view of a new biological scenario. The biome could be considered a compilation of three complementary parts: genome, transcriptome and proteome. Functional genomes will provide the linking of genetic variability and phenotype of organisms. The importance of that becomes evident since all physiological and pathological processes are results of gene expression.

Two-dimensional electrophoresis of proteins creates reproducible proteomic maps. Nowadays, individual protein spots can be unambiguously identified using MALDI-TOF ${ }^{10}$. In addition, several methodologies are available for analysis of differential gene expression at the level of genes and their first products ${ }^{37}$. Single and double nucleic 
acid strands can be physical-chemically separated by hydroxyapatite chromatography ${ }^{6}$. It is possible to subtract differential DNA sequences in a comparative study. The DNA subtraction methodology coupled with PCR has gained sensibility ${ }^{12,21}$. The differential display of mRNA allows the comparative analysis of several transcripts at the same time, using combination of an oligo-dT anchored primer and arbitrary primers in a reverse transcriptase PCR approach ${ }^{19}$. Normalization of cDNA libraries has increased the chance of detection of very poor expressed genes, since it almost equalizes the relative quantity of cDNA molecules ${ }^{3,33}$.

Currently, the DNA microarray (DNA chip) represents the most promising biotechnological tool for the analysis of functional genome. An array of several known DNA sequences is linked onto a small glass surface. Two DNA populations are labeled with different fluorochromes. Comparative hybridization can be performed in this DNA matrix simultaneously. Upon hybridization, the DNA chip is scanned in attempt to detect epifluorescence spots. The automated analysis distinguishes differences of hybridization of even 2 fold approximately ${ }^{8,22,26}$. The DNA chip requires a very small area, which means reduction of the volume of hybridization with consequent higher probe concentration and sensitivity. Robotic technology can design large-scale and high-density microarrays. Thus, thousands of sequences can be quickly screened at once by using automated procedures ${ }^{26}$.

In fact, DNA microarray is a high-throughput technology for gene expression analysis, which allows the monitoring of genes related to tissue specificity, biochemical pathways, pathogenesis, drug effects, drug metabolism and any other cellular stress ${ }^{5,14,29}$. Moreover, it is a rapid approach for detecting mutations in human disease genes, mapping disease genes by linkage analysis and discovering novel gene polymorphisms ${ }^{11,20,41}$.

Prospects for the biomedical research at this new millenium: The employment of these sophisticated biotechniques can provide further advancements of the biomedical science. Investigators are able to sequence a genome of any specie theoretically. The linear DNA sequence must be organized to give information about the genome organization, potential opening reading frames, intergenic sequences. Homology comparisons must be explored to reveal gene functions and protein modeling. The genes and related sequences could be catalogued in aspects of their functions such as cell metabolism, division, growth. In case of parasite genomes we could find genetic determinants of virulence, vaccine candidate, drug and diagnostic targets. For this reason, we understand bioinformatics as a necessary and powerful tool which can lead to interpretation and organization of sequence data generated by the study of the biome.

We consider that the coupling of genome projects with expression analysis would be the great advancement of the biomedical research in a brief future. It will be continuously necessary to decode genomes but also to give functions for the new sequences. This will answer the whole function of a living parasite, how it becomes a pathogen. Other intriguing aspects will be elucidated, such as the role of genetic polymorphism in host adaptation, parasite virulence and drug resistance.

The comprehension of pathological events at molecular level and the characterization of these particular genes and polymorphisms will provide us a way for intervention. Once it may be possible to identify genetic risk groups and virulent parasite strains, specific preventive or therapeutic intervention could be targeted. In addition, there are several unknown genes which are fundamental for parasite surviving, others can possess specific epitopes that whenever displayed result in protective immunological response. These gene products must be good candidates for drug design and vaccines. Comparative studies of genomes will reveal the biodiversity of parasites and their phylogenetic relationship.

Genetic markers are being taken in diagnosis of several pathogens ${ }^{13,23,25}$. Molecular diagnosis will be soon a medical practice worldwide for a large range of parasitic and genetic disorders. Several diseases can share symptoms which complicates an accurate diagnosis, even with clinical suspicion. Molecular diagnosis will be a medical tool for a sensible and precise diagnosis diminishing the suffering of patients. Genetic markers will indicate predisposition for some diseases prospecting the appearance of genetic disorder in a period of life. Thus, genetic predisposition diseases such as cancer, cardiovascular disorders and Alzheimer could be warned out early allowing individual prevention through behavior aspects and routine medical exams.

In summary, current achievements of molecular genetics and the development of bioinformatics are creating fantastic tools for the biomedical research, prospecting new scientific discoveries. Among ethical and biosecurity aspects, the biotechnology must be considered as the rational utilization of this knowledge and tools in taking benefits for the humanity, producing food and providing health quality. In this new millenium, the improvement of human life through the use of biotechnology appears to be a real promise to deal with overcrowding world, scarce of genetic resources and life quality in a sustainable development.

\section{RESUMO}

\section{Uma perspectiva histórica e prospecções da pesquisa biomédica em doenças parasitárias}

Espera-se que os grandes avanços da pesquisa de genomas alcancem saltos visíveis para a sobrevivência da humanidade dentro do contexto de sustentabilidade global. Vemos atualmente a necessidade imediata de incrementar a produção de alimentos e melhorar a qualidade de vida e saúde humana, mantendo a biodiversidade preservada. A biotecnologia é a utilização racional das ferramentas geradas pela biologia molecular e genética moderna que, dado ao grande avanço dessas áreas, poderá em breve responder essas novas questões. Este trabalho, escrito por três gerações de pesquisadores, inicia com uma perspectiva histórica da pesquisa biomédica em doenças parasitárias nos últimos séculos em nosso país. Em seguida, descrevemos os mais recentes avanços da biologia molecular e genética genômica. Ressaltamos a importância dessas novas conquistas dentro de uma prospecção da pesquisa biomédica deste século e seus possíveis impactos na saúde humana.

\section{ACKNOWLEDGEMENTS}

We thanks Universidade Católica de Brasília and CNpq for the financial support recently approved for the genome project of the bacteria Chromobacterium violaceum which is coordinated by Dr. Dario Grattapaglia. 


\section{REFERENCES}

1. ADAMS, M.D.; KERLAVAGE, A.R.; FIELDS, C. \& VENTER, J.C. - 3,400 new expressed sequence tags identify diversity of transcripts in human brain. Nature Genet., 4: 256-267, 1993.

2. BLACKWELL, J.M. \& MELVILLE, S.E. - Status of protozoan genome analysis: trypanosomatids. Parasitology, 118(suppl.): S11-S14, 1999.

3. BONALDO, M.F.; LENNON, G. \& SOARES, M.B. - Normalization and subtraction: two approaches to facilitate gene discovery. Genet. Res., 6: 191-806, 1996.

4. DAVENPORT, M.P. \& HILL, A.V.S. - Reverse immunogenetics: from HLA-disease associations to vaccine candidates. Molec. Med. today, 2: 38-45, 1996.

5. DeRISI, J.L.; IYER, V.R. \& BROWN, P.O. - Exploring the metabolic and genetic control of gene expression on a genomic scale. Science, 270: 680-686, 1997.

6. DUGUID, J.R. \& DINAUER, M.C. - Library subtraction of in vitro cDNA libraries to identify differentially expressed genes in scrapie infection. Nucleic Acids Res., 18: 2789-2792, 1990 .

7. FUNDAÇÃO NACIONAL DE SAÚDE. Centro Nacional de Epidemiologia. Inf. Epidem. SUS, 1(5): 139-148, 1992.

8. GERHOLD, D.; THOMAS, R. \& CASKEY, C.T. - DNA chips: promising toys have become powerful tools. Trends Biochem. Sci., 24:168-173, 1999.

9. GOTCH, F.; MCDAM, S.N.; ALLSOPP, C.E. et al. - Cytotoxic T cells in HIV2 seropositive Gambians. Identification of a HIV-2 virus-specific MHC-restricted peptide epitope. J. Immunol., 151: 3361-3369, 1993.

10. GRIMM, R.; GRASSER, K.D.; KUBACH, J. \& HANCOCK, W.S. - A rapid and sensitive procedure for the micro-purification and subsequent characterization of peptides and protein samples by $\mathrm{N}$-terminal sequencing and matrix assisted laser desorption ionization time of flight mass spectrometry. J. pharm. biomed. Anal., 18: 545-554, 1998.

11. HACIA, J.G.; BRODY, L.C.; CHEE, M.S.; FODOR, S.P.A. \& COLLINS, F.S. - Detection of heterozygous mutations in BRCA1 using high-density oligonucleotide arrays and two colour fluorescence analysis. Nature Genet., 14: 441-447, 1996.

12. HARA, E.; KATO, T.; NAKADA, S.; SEKIYA, S. \& ODA, K. - Subtractive cDNA cloning using oligo(dT)30-latex and PCR: isolation of cDNA clones specific to undifferentiated human embryonal carcinoma cells. Nucleic Acids Res., 19: 7097-7104, 1991.

13. HARNETT, W.; BRADLEY, J.E. \& GARATE, T. - Molecular and immunodiagnosis of human filarial nematode infections. Parasitology, 117(suppl.): S59-S72, 1998.

14. HELLER, R.N.; SCHENA, M.; CHAI, A. et al. - Discovery and analysis of inflammatory disease-related genes using cDNA microarrays. Proc. nat. Acad. Sci. (Wash.), 94: 2150-2155, 1997

15. HILL, A.V.S. - Malaria resistance genes; a natural selection. Trans. roy. Soc. trop. Med. Hyg., 86: 225-226, 1992.

16. HOPKINS, R.M.; CONSTANTINE, C.C.; GROTH, D.A. et al. - PCR-based DNA fingerprinting of Giardia duodenalis isolates using the intergenic rDNA spacer. Parasitology, 118: 531-539, 1999.

17. HOPKINS, R.M.; MELONI, B.P.; GROTH, D.M. et al. - Ribosomal RNA sequencing reveals differences between the genotypes of Giardia isolates recovered from humans and dogs living in the same locality. J. Parasit., 83: 44-51, 1997.

18. LANDER, E.S. - The new genomics: global views of biology. Science, 274: 536-539, 1996.

19. LIANG, P. \& PARDEE, A.B. - Differential display of eukaryotic messenger RNA by means of the polymerase chain reaction. Science, 257: 967-971, 1992.

20. LIPSHUTZ, R.J.; MORRIS, D.; CHEE, M. et al. - Using oligonucleotide probe arrays to access genetic diversity. Biotechnique, 19: 442-447, 1995.
21. LUQMANI, Y.A. \& LYMBOURA, M. - Subtraction hybridization cloning of RNA amplifies from different cell populations microdissected from cryostat tissue sections. Analyt. Biochem., 222: 102-109, 1994.

22. MARSHALL, A. \& HODGSON, J. - DNA chips: an array of possibilities. Nature Biotech., 16: 27-31, 1998.

23. McKEAND, J.B. - Molecular diagnosis of parasitic nematodes. Parasitology, 117(suppl.) S87-S96, 1998.

24. MELONI, B.P.; LYMBERY, A.J. \& THOMPSON, R.C.A. - Genetic characterization of isolates of Giardia duodenalis by enzyme electrophoresis: implications for reproductive biology, population structure, taxonomy and epidemiology. J. Parasit., 81: $368-383,1995$

25. MORGAN, U.M. \& THOMPSON, R.C.A. - Molecular detection of parasitic protozoa. Parasitolology, 117(suppl.): S73-S85, 1998.

26. RAMSAY, G. - DNA chips: state-of-the art. Nature Biotech., 16: 40-44, 1998.

27. RISCH, N. - Linkage strategies for genetically complex traits. II. The power of affected relative pairs. Amer. J. hum. Genet., 46: 229-241, 1990.

28. ROSEN, G. - Da polícia médica à medicina social: ensaios sobre a história da existência médica. Rio Janeiro, Graal, 1980.

29. SCHENA, M.; SHALON, D.; HELLER, R. et al. - Parallel human genome analysis: microarray-based expression monitoring of 1000 genes. Proc. nat. Acad.Sci. (Wash.), 93: 10614-10619, 1996

30. SCHULER, G.D.; BOGUSKI, M.S.; STEWART, E.A. et al. - A gene map of the human genome. Science, 274: 540-567, 1996.

31. SCLIAR, M. - Do mágico ao social: a trajetória da saúde pública. Porto Alegre, L \& PM, 1987.

32. SINGER, P.; CAMPOS, O. \& OLIVEIRA, E.M. - Prevenir e curar: o controle social através dos serviços de saúde. Rio Janeiro, Forense Universitária, 1978.

33. SOARES, M.B.; BONALDO, M.F.; JELENE, P. et al. - Construction and characterization of a normalized cDNA library. Proc. nat. Acad. Sci.(Wash.), 91: 9228-9232, 1994.

34. THOMPSON, R.C.A. \& LYMBERY, A.J. - Genetic variability in parasites and hostparasite interactions. Parasitology, 112(suppl.): S7-S22, 1996.

35. TOOD, J.R.; WEST, B.C. \& McDONALD, J.C. - Human leukocyte antigen and leprosy: study in northern Lousiana and review. Rev. infect. Dis., 12: 63-74, 1990.

36. VANEDEN, W.; De VRIES, R.R.; MEHRA, N.K. et al. - HLA segregation of tuberculoid leprosy: confirmation of the DR2 marker. J. infect. Dis., 141: 693-701, 1980.

37. VEDOY, C.G.; BENGTSON, M.H. \& SOGAYAR, M.C. - Hunting for differentially expressed genes. Braz. J. med. biol. Res., 32: 877-884, 1999.

38. WAKELIN, D. \& BLACKWELL, J.M., eds. - Genetics of resistance to bacterial and parasitic infections. London, Taylor and Francis, 1988.

39. WALDMAN, E.A.; SILVA, L.J. \& MONTEIRO, C.A. - Trajetória das doenças infecciosas: da eliminação da poliomielite à reintrodução da cólera. Inf. Epidem. SUS, 8(3): 05-48, 2000.

40. WILLIAMS, S.A. \& JOHNSTON, D.A. - Helminth genome analysis: the current status of the filarial and schistosome genome projects. Filarial Genome Project. Schistosome Genome Project. Parasitology, 118(suppl.): S19-S38, 1999.

41. YERSHOV, K.; BARSKY, V.; BELGOVSKIY, A. et al. - DNA analysis and diagnosis on oligonucleotide chips. Genetic, 93: 4913-4918, 1996

Received: 26 March 2001

Accepted: 26 April 2001 